Vol. 8, Issue 8, August 2021

DOI: $10.17148 / I A R J S E T .2021 .8854$

\title{
A Study on Challenges Faced By CSR Company Employees Work From Home During Lockdown
}

\author{
Mrs. Helen Sha Diana ${ }^{1}$, Ms. Janan ${ }^{2}$ \\ ${ }^{1}$ Assistant Professor, PG Department of Social Work, Shrimathi Devkunvar Nanalal Bhatt Vaishnav College for \\ Women, Chromepet, Chennai, TamilNadu, India \\ ${ }^{2}$ MSW Student, PG Department of Social Work, Shrimathi Devkunvar Nanalal Bhatt Vaishnav College for Women, \\ Chromepet, Chennai, TamilNadu, India
}

\begin{abstract}
The Companies Act, 1956 is replaced with The Companies Act, 2013 and 'corporate social responsibilities' (CSR) has been made mandatory for a particular class of companies. There has to be an all-inclusive growth of the society with the growth of the companies. In this article, we offer some initial examination on how Covid-19 pandemic can influence the developments of CSR and marketing. We argue that Covid-19 pandemic offers a great opportunity for businesses to shift towards more genuine and authentic CSR and contribute to address urgent global social and environmental challenges. We also discuss some potential directions of how consumer ethical decision making will be shifted to due to the pandemic. In our discussion of marketing, we outline how we believe marketing is being affected by this pandemic and how we think this will change, not only the context of marketing, but how organizations approach their strategic marketing efforts. We end the paper with a identifying a number of potentially fruitful research themes and directions.
\end{abstract}

Keywords: Covid-19, Corporate social responsibility, Marketing, Consumer ethical decision making, Marketing philosophy, Business ethics

\section{INTRODUCTION:}

The importance of CSR emerged significantly in the last decade. Over the time, CSR expanded to include both economic and social interests. Along with this it also broadened to cover economic as well as social interests. Companies have become more transparent in accounting and display public reporting due to pressures from various stakeholders. It is possible for companies to behave in the desired ethical and responsible manner towards consumers, employees, communities, stakeholders and environment. They have started incorporating their CSR initiative in their annual reports. CSR is an entry point for understanding a number of firm-related and societal issues and responding to them in a firm 's business strategy. However, there is a universal and prominent view on protecting the environment and stakeholders' interests. We do know is that the world has changed. Like other global events with planet-wide impact, Covid-19 could potentially change how we see the world, the ways in which we think, and how we conduct our lives.

\subsection{CONCEPT OF CORPORATE SOCIAL RESPONSIBILITY:}

The word responsibility implies that business organization has some kind of obligation towards the society in which they function to deal with social problems and contribute more than just economic services. Corporate social responsibility means conducting business in an ethical way and in the interests of the wider community and responding positively to emerging societal priorities and expectations. It is a willingness to act ahead of regulatory confrontation and balancing shareholder interests against the interests of the wider community for becoming a good citizen.

\subsection{ISSUES OF CSR}

- The Shrinking Role of Government

- $\quad$ Demands For Greater Disclosure

- Increased Customer Interest

- $\quad$ Growing Investor Pressure

- $\quad$ Competitive Labour Markets

- $\quad$ Supplier Relations 
DOI: 10.17148/IARJSET.2021.8854

1.3. CHALLENGES OF CSR

- $\quad$ Lack of Community Participation in CSR Activities

- $\quad$ Need to Build Local Capacities

- $\quad$ Issues of Transparency

- $\quad$ Non-availability of Well Organized Non-Governmental Organizations

- Visibility Factor

- Narrow Perception towards CSR Initiatives

- $\quad$ Non-availability of Clear CSR Guidelines

- $\quad$ Lack of Consensus on Implementing CSR Issues

\section{REVIEW OF LITERATURE:}

How companies can maintain employee mental health in the time of Covid-19: June 13, 2020

Corporates have always had a critical role to play in India's development and progress. In these testing times of the Covid19 pandemic and the resulting lockdown, the contribution of corporates has become even more invaluable if we are to bounce back stronger as a nation. However, organisations are now having to deal with an entirely new spectrum of issues, much of it having to do with the mental health of their employees. Unfortunately, isolation from society, the inflow of bleak coronavirus-related information, the fear of contracting Covid-19, the looming economic recession.

\section{METHODOLOGY}

\section{SPECIFIC OBJECTIVES:}

- $\quad$ To study the CSR status in India.

- To understand the meaning and various models of CSR.

- $\quad$ To study the policies governing CSR in India.

- $\quad$ To study the issues \& challenges faced by CSR in India.

- $\quad$ To make suggestions for accelerating CSR initiatives.

RESEARCH DESIGN: DESCRIPTIVE RESEARCH DESIGN

SAMPLING DESIGN: Non-Probability Sampling Method (Convenience Sampling)

\section{SAMPLING SIZE:25}

\section{SAMPLING CRITERIA:}

The data will be collected from the corporate employee in Chennai

\section{DATA TABLES \& ANALYSIS}

\section{TABLE:1}

\begin{tabular}{|c|c|c|c|}
\hline S.NO & $\begin{array}{c}\text { INCOME BEFORE } \\
\text { LOCKDOWN }\end{array}$ & FREQUANCY & PERCENTAGE \\
\hline 1 & LESS THAN 20,000 & 7 & 28 \\
\hline 2 & $20,000-40,000$ & 11 & 44 \\
\hline 3 & $40,000-60,000$ & 6 & 0 \\
\hline 4 & $60,000-80,000$ & 0 & 4 \\
\hline 5 & MORE THAN 80,000 & 1 & 100 \\
\hline & TOTAL & 25 & 24 \\
\hline
\end{tabular}

From the above Table:10 it is clear that the majority of the employee income response belong to 20,000-40,000 during lockdown $44 \%$ 


\section{FIG:1}

INCOME BEFORE THE LOCKDOWN

25 responses

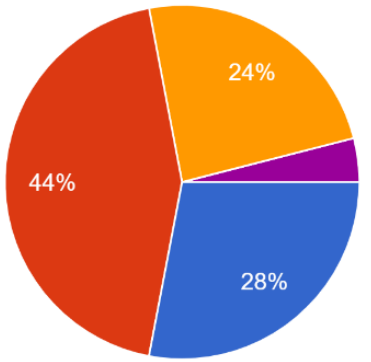

LESS THAN 20,000

$20,000-40,000$

$40,000-60,000$

$60,000-80,000$

MORE THAN 80,000

From the above Fig:10 it is clear that the majority of the employee income response belong to 20,000-40,000 before lockdown $44 \%$

TABLE:2

\begin{tabular}{|c|c|c|c|}
\hline S.NO & $\begin{array}{c}\text { INCOME AFTER } \\
\text { LOCKDOWN }\end{array}$ & FREQUENCY & PRECENTAGE \\
\hline 1 & LESS THAN 15,000 & 8 & 32 \\
\hline 2 & $15,000-35,000$ & 14 & 56 \\
\hline 3 & $35,000-55,000$ & 3 & 0 \\
\hline 4 & $55,000-75,000$ & 0 & 0 \\
\hline 5 & MORE THAN 75,000 & 0 & 120 \\
\hline
\end{tabular}

From the above Table 11 it is clear that the majority of the employee income response belong to 15,000-35,000 after lockdown $56 \%$

FIG:2

INCOME AFTER THE LOCKDOWN

25 responses

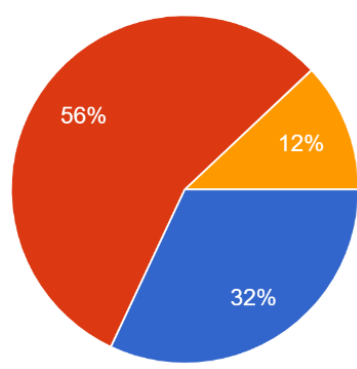

LESS THAN 15,000

$15,000-35,000$

$35,000-55,000$

$55,000-75,000$

MORE THAN 75,000

From the above Fig 11 it is clear that the majority of the employee income response belong to 15,000-35,000 after lockdown $56 \%$

TABLE:3

\begin{tabular}{|c|c|c|c|}
\hline S.NO & $\begin{array}{c}\text { DUE TO COVID AFFECTED } \\
\text { ECONOMICALLY }\end{array}$ & FREQUENCY & PRECENTAGE \\
\hline 1 & YES & 21 & 84 \\
\hline 2 & NO & 4 & 8 \\
\hline 3 & MAY BE & 4 & 100 \\
\hline
\end{tabular}

From the above Table 12 it is clear that the majority of the responses affected economically due to covid belong to $84 \%$ 


\section{FIG:3}

\section{DUE TO COVID YOU AFFECTED ECONOMICALLY}

25 responses
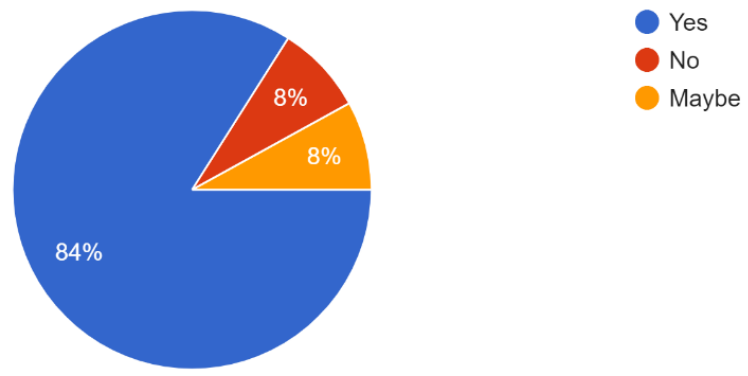

From the above Fig 12 it is clear that the majority of the responses affected economically due to covid belong to $84 \%$

\section{TABLE:4}

\begin{tabular}{|c|c|c|c|}
\hline S.NO & $\begin{array}{c}\text { DID YOU GOT } \\
\text { UNEMPLOYMENT DUE } \\
\text { TO COVID }\end{array}$ & FREQUENCY & PRECENTAGE \\
\hline 1 & YES & 4 & 16 \\
\hline 2 & NO & 15 & 60 \\
\hline 3 & MAYBE & 6 & 24 \\
\hline & TOTAL & 25 & 100 \\
\hline
\end{tabular}

From the above Table 13 it is clear that the majority of the response Not got unemployment due to covid belong $60 \%$

\section{FIG:4}

DID YOU GOT UNEMPLOYMENT DUE TO COVID

25 responses
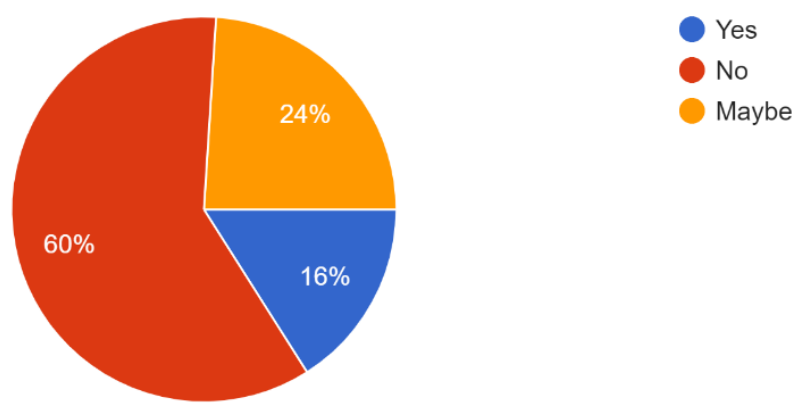

From the above Fig 13 it is clear that the majority of the response Not got unemployment due to covid belong $60 \%$

\section{FINDINGS}

- $\quad$ The majority of the employee income response belong to 20,000-40,000 during lockdown $44 \%$

- The majority of the employee income response belong to 15,000-35,000 after lockdown 56\%

- The majority of the responses affected economically due to covid belong to $84 \%$

- The majority of the response Not got unemployment due to covid belong $60 \%$

- The majority of the response have Not spent time for them belong to $56 \%$

- $\quad$ The majority of the employee emotionally feels stress after working more time belong to $52 \%$

- The majority of the response had heavy work in this pandemic belong to $48 \%$

- The majority response belongs to $40 \%$ of CSR company have introduced new policies during lockdown 


\section{International Advanced Research Journal in Science, Engineering and Technology}

Vol. 8, Issue 8, August 2021

DOI: 10.17148/IARJSET.2021.8854

SUGGESTIONS:

- $\quad$ Companies can set a network of activities to be taken up in a consortium to tackle major environmental issues.

- $\quad$ It would also provide an opportunity to learn from each other. Everyone in the organization needs to recognize their own role in promoting CSR. Companies should provide wider professional development activities.

- $\quad$ Training, conferences and seminars could be organized by companies to disseminate and generate new knowledge and information in this sector.

- A strong budgetary support would definitely help to grow this sector and research related to respective industry would enhance their organization 's contribution further.

- Government regulations which are supporting in this direction could attract more response from organizations. All this would also lead to benchmark CSR activities.

- Companies need to involve their stakeholders in order to build meaningful and long-term partnerships which would lead to creating a strong image and brand identity.

- It is also suggested to review existing policies in order to develop more meaningful visions for the companies and broaden their contributions to reach to local communities.

\section{CONCLUSION:}

The concept of corporate social responsibility is now firmly rooted on the global business agenda. But in order to move from theory to concrete action, many obstacles need to be overcome. A key challenge facing business is the need for more reliable indicators of progress in the field of CSR, along with the dissemination of CSR strategies. Transparency and dialogue can help to make a business appear more trustworthy, and push up the standards of other organizations at the same time.

\section{REFERENCES:}

1. Austin, James E. The Collaboration Challenge: How Non-profits and Businesses succeed through Strategic Alliances, Jossey-Bass, San Francisco, 2000, Page no- 2-11.

2. B. Scholtens, -Finance as a Driver of Corporate Social Responsibility, _Journal of Business Ethics, vol. 68, no. 1, pp. 19-33, sep 2006.

3. J. M. Rose, -Corporate Directors and Social Responsibility: Ethics versus Shareholder value, Journal of Business Ethics, vol. 73, no. 3, pp. 319-331, July 2007.

4. Karmayog Report. (2009). Retrieved from http://www.karmayog.org/csr2009

5. KvasničkováStanislavská, L., Margarisová, K., Št’astná, K, Corporate Social Responsibility in banking sector. Actauniv. agric. et silvic. Mendel. Brun., 2012, LX, No. 2, pp. 157-164.

\section{BIBLIOGRAPHY:}

http://en.m.wikipedia.org

$\mathrm{http}: / /$ timesofindia.indiatimes.com

www.economictimes.com 